\section{Evaluation of information technology certificate programs in terms of 21st century skills}

\author{
Hasan Çakır ${ }^{1}$ \\ Ömer Delialioğlu ${ }^{2}$ \\ Emre Özgül ${ }^{3}$
}

\section{Bilgi teknolojileri sertifika eğitim programlarının 21. yüzyıl becerileri açısından değerlendirilmesi}

\section{Abstract}

The purpose of this study is to determine the effectiveness of an IT certificate program that contributes to the career development of individuals in terms of gaining 21 st century skills, given the increasing competitive conditions of globalization process and developments in Information Technologies (IT). This study covers the Cisco Certified Network Associate (CCNA) Certificate Program in Vocational and Technical High Schools in collaboration with Cisco Networking Academy, one of the important institutions among IT certification programs. This certificate program provides training to students in the department of information technologies and electricalelectronics technologies in vocational high schools in order to meet the labor demands in the field of computer networks technology in Turkey. This certificate program is a comprehensive study starting in 2011-2012 academic year and completed in two years. However, the scope of this study is limited to the comparison of demographic characteristics and 21st century skill levels of students participating and non-participating in the certificate program. The study was conducted

\section{Özet}

Küreselleşme sürecinin artan rekabetçi koşulları ve Bilgi Teknolojilerinde (BT) yaşanan gelişmeler göz önüne alındığında, bireylerin kariyer gelişimlerine katk1 sağlayan sertifika eğitim programlarının 21. yüzyll becerilerinin kazandirılması bakımından ne derece etkili olduğunun ortaya konması bu çalışmanın amacını oluşturmaktadır. Bu çalışmada, BT sertifika eğitim programları arasında önemli kuruluşlardan biri olan Cisco Networking Academy işbirliği ile Mesleki ve Teknik Liselerde gerçekleştirilen Cisco Certified Network Associate (CCNA) Sertifika Programı ele alınmıştır. Bu sertifika programı, Türkiye'deki bilgisayar ağları teknolojisi alanındaki işgücü taleplerini karşılamak maksadiyla meslek liselerinin bilişim ve elektrik-elektronik teknolojileri alanlarındaki öğrenciler için eğitimler düzenlemektedir. Bu sertifika eğitim programının değerlendirilmesi 2011-2012 eğitim-öğretim yllinda başlayan ve iki yılda tamamlanan kapsamlı bir çalısmadır. Ancak mevcut çalışmanın kapsamı, eğitim programının birinci yllinda sertifika programina katilan öğrenciler ile katılmayan öğrencilerin demografik özellikler ve 21. yüzyıl beceri düzeyleri

\footnotetext{
${ }^{1}$ Doç. Dr., Gazi Üniversitesi, Eğitim Fakültesi, Bilgisayar ve Öğretim Teknolojileri Eğitimi, hasanc@gazi.edu.tr

2 Doç. Dr., Orta Doğu Teknik Üniversitesi, Eğitim Fakültesi, Bilgisayar ve Öğretim Teknolojileri Eğitimi, omerd@metu.edu.tr

${ }^{3}$ Öğr. Gör., Bülent Ecevit Üniversitesi, Devrek Meslek Yüksekokulu, Bilgisayar Teknolojileri, emreozgul@,beun.edu.tr
} 
Çakır, H., Delialioğlu, Ö., \& Özgül, E. (2019). Bilgi teknolojileri sertifika eğitim programlarının 21. yüzyıl becerileri açısından değerlendirilmesi. Journal of Human Sciences, 16(4), 998-1013. doi:10.14687/jhs.v16i4.5704

with 1453 students and the majority of these students were male. According to the findings of the study, it was concluded that the students who participated in the certificate program had a high level of skills in terms of 21 st century skills. In addition, there was no effect of gender among students participating in technologybased certificate programs.

Keywords: Certificate programs; 21st century skills; computer networks; information technologies.

(Extended English summary is at the end of this document) bakımından karşılaştırılması ile sınırlıdır. Araştırma toplamda 1453 öğrenci ile gerçekleştirilmiş olup bu öğrencilerin çoğunluğu erkeklerden oluşmaktadır. Çalışmanın bulgularına göre, sertifika programına katılan öğrencilerin kattlmayan öğrencilere göre 21. yüzyıl becerileri bakımından birçok düzeyde yüksek becerilere sahip oldukları ve teknoloji ağırlıklı sertifika eğitim programlarına katılan öğrenciler arasında cinsiyete bağlı dezavantajlı grupların oluşmadığı sonucuna ulaşılmıştır.

Anahtar Kelimeler: Sertifika programlar1; 21. yüzyıl becerileri; bilgisayar ağlar1; bilgi teknolojileri.

\section{Giriş}

Günümüzde Bilgi ve İletişim Teknolojileri (BİT) kullanım alanlarının artması ile nitelikli ve sürdürülebilir işgücüne ihtiyaç giderek artmaktadır. Böylesi bir işgücünün oluşturulması ve devamlılığının sağlanması için uzman becerilere sahip Bilgi Teknolojisi (BT) çalışanlarının yetiştirilmesi ve endüstriye kazandırılması gerekmektedir. Bilgisayar teknolojilerindeki hızlı değişim, geleneksel eğitimin yavaş ilerleyişi ve teknik becerilere sahip bireylerin alana kazandırılması gibi zorluklar, BT Endüstrisinin ihtiyaç duyulan işgücü talebini karşılamak adına kendi sertifika eğitim programlarını başlatmasına neden olmuştur (Clarke, 2001). Sertifikalar, BT becerilerini kazandırmak için geleneksel eğitime destekleyici araçlardır ve tanımlanmış alanlarda bir yeterlilik standardı kurmayı amaçlamaktadır. Sertifikasyon, Cantor (2002)'a göre "belirli bir meslek ya da mesleğe ilişkin uzmanlık alanındaki yeterli bilgi ve becerinin bir teyidi" olarak tanımlamaktadır. Geleneksel akademik derecelerin aksine sertifikalar, dar alanlara veya tek bir ürüne özgü olma eğiliminde olup, çalışma ortamlarında anında uygulanabilir ve hedefli becerilerin sağlanması için tasarlanmışır (McGill \& Dixon, 2004).

BT sertifika programları hem yeni beceriler geliştirmek isteyen öğrencilere hem de yeteneklerini yükseltmek isteyen profesyonellere ucuz ve yoğun bir çalışma ortamı sağlamaktadır (CompTIA, 2017). Birleşik Devletlerde (ABD) mevcut teknoloji sertifika eğitim programları öncelikle yetişkin öğrenciler tarafından doldurulmaktadır (Meares \& Sargent, 2003; Delialioğlu vd., 2010). Bu sertifika programlarının çoğunluğu, öğrenci başarısını ölçmek için öğrencilerin belirli bir yeterlilik seviyesine ulaşması gereken performansa dayalı değerlendirme sistemlerini kullanmaktadır (Adelman, 2000).

McGill ve Dixon (2004) Katılımciların sertifika programlarından bekledikleri faydaları: Daha fazla bilgi ve artan verimlilik, belli bir uzmanlık ve beceri seviyesi, geliştirilmiş destek kalitesi, eğitim masraflarının azaltılması ve yüksek motivasyon ve bağlılı̆̆ sağlama olarak sıralamaktadır. Eğitim kurumları açısından sertifika programları, program içeriklerinin genişletilmesi ve değerlendirme kapasitesinin arttırılmasına olanak sağlaması bakımından büyük fayda sağlamaktadır (Ray \& McCoy, 2000).

Teknolojiye özel sertifikaların ilk olarak Novell (yazılım şirketi) tarafindan 1989'da sunulduğu kabul edilmektedir (Randall \& Zirkle, 2005; Hitchcock, 2005; Adelman, 2000). BT sertifikalar1, 1990’lı yıllardan beri BT kariyer alanı ve alt alanlarında sayıca ve etki alanı bakımından giderek artmaktadır (Adelman, 2000). Güçlü bir ekonomiye sahip ülkelerde dahi bilgi teknolojisi hızla büyüyen bir alandır ve BT uzmanlarının sahip olduğu bilgi geniş bir alanı kapsamaktadır. BT sertifikaları nitelikli, bilgili çalısanların eğitilmesi ve belirlenmesine ve bu çalışanların doldurulması gereken iş pozisyonlarıyla eşleştirilmesine yardımcı olmaktadır (CompTIA, 2017). 
Çakır, H., Delialioğlu, Ö., \& Özgül, E. (2019). Bilgi teknolojileri sertifika eğitim programlarının 21. yüzyıl becerileri açısından değerlendirilmesi. Journal of Human Sciences, 16(4), 998-1013. doi:10.14687/jhs.v16i4.5704

Birleşik Devletler Çalışma Bakanlığı (2017) tarafindan hazırlanan 2016-2026 yılları arasında BT alanlarındaki istihdam oranları (Tablo 1) incelendiğinde yakın gelecekte bilgisayar disiplinlerinde içerisinde yeni bilgisayar ağı uzmanlarına (Bilgisayar Ağları Mimarisi, A $\breve{g}$ ve Bilgisayar Sistem Yöneticileri ve Bilgisayar Ağları Destek Uzmanı) ihtiyacın giderek artacağı görülmektedir.

Tablo 1. 2016 - 2026 (Beklenen) Yıllarına Ait Mesleklere Göre İstihdam Sayıları (Amerika Birleşik Devletleri)

\begin{tabular}{|c|c|c|c|c|}
\hline \multirow{2}{*}{2016 Ulusal İstihdam Matrisi } & \multicolumn{2}{|c|}{ Çalışan Sayısı } & \multirow{2}{*}{$\begin{array}{c}\text { Değişim } \\
16-26\end{array}$} & \multirow{2}{*}{$\begin{array}{c}\text { Yüzde } \\
\%\end{array}$} \\
\hline & 2016 & 2026 & & \\
\hline Bilgisayar Programcilar1 & 294.900 & 272.300 & -22.600 & -7.6 \\
\hline Yazılım Geliştiriciler (Uygulamalar) & 831.300 & 1.084 .600 & 253.400 & 30.5 \\
\hline Yazılım Geliştiriciler (Sistem Yazılımı) & 425.000 & 471.000 & 46.100 & 10.8 \\
\hline Veritabanı Yöneticileri & 119.500 & 133.200 & 13.700 & 11.5 \\
\hline $\begin{array}{l}\text { * Veritabanı ve Sistem Yöneticileri, A } \breve{g} \\
\text { Mimarisi }\end{array}$ & 673.400 & 721.400 & 48.000 & 7.1 \\
\hline * A ̆g ve Bilgisayar Sistem Yöneticileri & 391.300 & 415.200 & 23.900 & 6.1 \\
\hline * Bilgisayar Ağları Mimarisi & 162.700 & 173.100 & 10.400 & 6.4 \\
\hline * Bilgisayar Ağları Destek Uzmanı & 198.800 & 214.800 & 16.000 & 8.1 \\
\hline Diğer Tüm Bilgisayar Uzmanları & 209.300 & 236.800 & 27.500 & 13.14 \\
\hline Bilgisayar Donanımı Mühendisleri & 73.600 & 77.600 & 4.000 & 5.5 \\
\hline
\end{tabular}

$*$ : Bilgisayar ağları ile ilgili meslek alanları

BT alanında uzmanlar, endüstri sertifikalarıla bilgilerini sergileyebilmektedir. Bu sertifikalar genellikle sağlayıcılara özgü sertifikalar (Microsoft, Cisco, Oracle, IBM vb.) veya sağlayıcılardan bağımsız sertifikalar (CompTIA, (ISC) ${ }^{2}$, SANS vb.) şeklindedir (Gomilion, 2017). Sağlayıcılara özgü sertifikalar, genelde ücretli olmakla birlikte sinırlı bir alan üzerinde belli bilgi ve becerilerin kazandırılmasına yönelik çözümler sağlarken, sağlayıcılardan bağımsız sertifikalar kâr amacı gütmeyen kuruluşlar ve endüstri dernekleri tarafindan belli bir alandan ve sağlayıcıdan ziyade birden çok sağlayıcıya özgü genel bilgi ve becerilerin kazandırılmasına yönelik çözümler sunmaktadır. Sağlayıcılara özgü sertifikasyon programlarının avantajları şu şekilde sıralanabilir (Bird, 2001; Randall \& Zirkle, 2005):

- Belirli teknolojiler ve ürünler hakkında ayrıntılı talimatlar sağlar.

- Ürünün popülerliğine göre endüstri çapında tanınabilirliği artırır.

- Mevcut ve yaygin olarak kullanılan ürünlere göre müfredat uygulanır.

- Kitaplar, eğitim materyalleri ve forumlar gibi destekleyici öğrenme araç gereçleri mevcuttur.

- Sağlayıcılara özgü sertifikalar genel olarak dünya çapında tanınırken, sağlayıcılardan bağımsız sertifikalarda bu durum daha sinırlı olmaktadır.

Ortaöğretim ve Lise sonrası eğitim kurumlarında sunulan sağlayıcılara özgü sertifikasyon programlarından birine örnek olarak "Cisco Networking Academy" verilebilir. Cisco (2004), Stanford Üniversitesi'nden bir grup bilgisayar bilimcisi tarafindan 1984 yilinda kurulmuştur ve şu anda İnternet Protokolü tabanlı ă̆ teknolojilerinin geliştirilmesi ve sunumunda küresel bir lider konumundadır. The Cisco Networking Academy, 1997 yllindan beri 6 milyondan fazla bireyin BT alanında işgücüne katılmasını sağlamıştır. Cisco Networking Academy, bünyesinde çeşitli sertifika programları sunmaktadır ancak bunlar içerisinde en popüler olanı Cisco Certified Network Associate (CCNA) programıdır. Dört ders bölümünden oluşan CCNA programı, 150'den fazla ülkede 10.000'in üzerinde lise, kolej ve geleneksel olmayan eğitim kurumları tarafindan uygulanmaktadır (Dennis, Duffy ve Çakır, 2010). 
Çakır, H., Delialioğlu, Ö., \& Özgül, E. (2019). Bilgi teknolojileri sertifika eğitim programlarının 21. yüzyıl becerileri açısından değerlendirilmesi. Journal of Human Sciences, 16(4), 998-1013. doi:10.14687/jhs.v16i4.5704

BT sertifika eğitim programlarının genelinde olduğu gibi CCNA programı da, yüz yüze ve çevrimiçi kursların birleşiminden oluşan, eğitmenlere ve öğrencilere benzersiz bir öğrenme ortamı sağlayan kısaca bir harmanlanmış öğrenme (blended learning) ortamı sunmaktadır. Harmanlanmış öğrenmenin alanyazında net bir tanımı olmamakla birlikte farklı kişilerce farklı anlamlar ifade ettiọ̆ görülmektedir (Rossett, Douglis \& Frazee, 2003; Oliver \& Trigwell, 2005; Dağ, 2011). Fakat harmanlanmış öğrenme genel olarak çevrimiçi eğitimin güçlü yönleri ile yüz yüze eğitimin güçlü yönlerinin birlikte kullanıldığı, İnterneti geleneksel, yüz yüze öğretimle birleştiren bir yaklaşım olarak düşünülebilir (Osguthorpe \& Graham, 2003). Yüz yüze eğitimde, eğitmenler derslerinin nasıl yürütüleceğine ve içeriğin öğrencilerin ihtiyaçlarına göre nasıl değiştirebileceğine karar vermede gerekli esnekliğe sahiptir. Diğer taraftan uygun bir Öğrenme Yönetim Sistemi (ÖYS) kullanılarak önceden hazırlanmış çevrimiçi ders materyalleri ile öğrencilerin ders dışı etkinlikler yoluyla bireysel öğrenmeleri sağlanabilmektedir.

Singh ve Reed (2001)'e göre harmanlanmış öğrenme; sadece farklı bilgi aktarım yöntemlerinin karıştırılması veya birlikte kullanılması değil, programın maliyeti ve programın öğrenme kazanımları açısından programdan en üst düzeyde verim elde etmeyi sağlayacak biçimde "doğru" öğrenme teknolojilerini "doğru" öğrenme stilleri ile ilişkilendirerek "doğru" yetenekleri "doğru” insana "doğru" zamanda aktarma işi olarak tanımlamaktadır (Dağ, 2011). Yapılan bu tanımlamaya bakılarak BT sertifika eğitim programlarının amaçları ile harmanlanmış öğrenme yaklaşımının benzer amaçlar doğrultusunda örtüştüğü görülmektedir.

BİT’lerin modern toplumda gittikçe yaygın hale gelmesi nedeniyle öğrencilerin bu teknolojilerle ilgili yetkinliklerini artırmak, 21. yüzyıl eğitiminin temel odağı haline gelmiştir (Hanson-Baldauf \& Hassell, 2009). BİT’lerin disiplinlerarası ve bilgi bakımından zengin doğası göz önüne alındığında, öğrencilerin 21. yüzyıl becerilerinin geliştirilmesinde oldukça etkili olduğu düşünülmektedir. Yakın tarihte hayatımıza giren ve birçok alanda sıkça karşılaşılan kavramlardan biri olan 21. yüzyıl becerileri, geleceğin dünyasına hazırlanırken bireylerin sahip olmaları gereken becerileri ifade etmektedir (Sing, 1991). Kritik düşünme, problem çözme, iletişim, işbirliği, bilgi ve teknoloji okuryazarlığı, esneklik ve adapte olabilme, küresel yetkinlikler ve finansal okur-yazarlık gibi temel özellikler temel 21. yüzyıl becerileri olarak tanımlanmaktadır (The Partnership for 21st Century Skills, 2008). 21. yüzyıl becerilerine ilişkin alanyazında yapılan araştırmalar incelendiğinde yukarıda sıralan becerilere ek olarak yaratıcılık ve yenilikçilik, hayat boyu öğrenme, liderlik ve kariyer farkındalı̆̆1 gibi beceriler de yine 21. yüzyıl becerileri olarak görülmektedir.

Küreselleşme sürecinin hız kazandığı günümüzde, çeşitli sektörlerde artan rekabet koşullarına bağlı olarak bireylerin kendileri geliştirmeleri kaçınılmaz bir durumdur. 21. yüzyıl becerileri içerisinde sıralanan yeterlilikler göz önüne alındığında bireyin kendini geliştirmesi, hem çağa ayak uydurmada hem de endüstri için gerekli işgücü kaynaklarının rasyonel kullanılması konusunda ilgililere birtakım faydalar sağlayacaktır. Bireyin uzmanlaşmak istediği iş alanına bağlı olarak kişisel gelişim süreci içerisinde sertifikaların önemli bir yere sahip olduğu düşünülmektedir.

\section{Problem Durumu}

21. yüzyıl gereksinimlerine paralel olarak gelişmiş ve gelişmekte olan ülkeler, eğitim sistemlerinde teknolojiden yararlanmaya, bu teknolojilerin etkili kullanımına ve geliştirilmesine katkı sağlamak amacıyla bireylerin yetiştirilmesine yönelik birtakım çalşmalar yürütmektedirler. $\mathrm{Bu}$ çalışmalardan biri olan teknoloji ağırlıklı sertifika eğitim programları, nitelikli, bilgili çalısanların eğitilmesi, belirlenmesi ve bu çalışanların sektöre kazandırılmasına yardımcı olmayı amaçlamaktadır. Geleneksel eğitim sisteminin günümüzün hızla değişen eğitim ihtiyaçlarına cevap vermede yetersiz kalan yönü, sertifika eğitim programlarını bireylerin güncel bilgilere erişimlerinin sağlanmasında önemli hale getirmektedir.

Alanyazın incelendiğinde, eğitim-öğretim ortamlarında kullanılan teknolojilerin sayısı her geçen gün artmasına rağmen bu teknolojilerin öğrenenler üzerinde ilgili 21. yüzyıl becerilerin kazandırılması ve geliştirilmesi bakımından yeterli düzeyde olmadıkları görülmüsstür (National Center for Education Statistics, 2000; Cuban, 2001; Evans \& Gunter, 2004; Sandholtz, Reilly, \& Haymore, 2004; Hanson-Baldauf \& Hassell, 2009). Oysa bireylerin iş hayatındaki rekabet ve 
Çakır, H., Delialioğlu, Ö., \& Özgül, E. (2019). Bilgi teknolojileri sertifika eğitim programlarının 21. yüzyıl becerileri açısından değerlendirilmesi. Journal of Human Sciences, 16(4), 998-1013. doi:10.14687/jhs.v16i4.5704

değişimlere uyum sağlayabilmeleri, başarılı olabilmeleri ve mesleki açıdan gelişim gösterebilmeleri için 21. yüzyıl becerilerine sahip olmaları beklenmektedir. 21. yüzyıl becerilerinin kazandırılması ve bu becerilerinin geliştirilmesinde kullanılacak yöntemlerden biri de harmanlanmış öğrenme ortamlarında gerçekleştirilen BT sertifika eğitim programlarıdır. Harmanlanmış öğrenme ile öğrenme-öğretme sürecinin hedef, içerik, öğretim materyalleri, zaman ve ortam gibi önemli bileşenleri göz önüne alındığında, yüz yüze ve çevrimiçi öğrenmenin dengeli bir şekilde birleştirilmesinin öğrenenler üzerinde eğitsel çıktılar ve ilgili 21. yüzyıl becerilerinin kazandırılması açısından birtakım faydaları bulunmaktadır (Çakır vd., 2009; Delialioğlu, Öncü ve Çakır, 2008; Dennis, Duffy ve Çakır, 2010; Delialioğlu vd., 2010).

Alanyazın incelendiğinde BT sertifika eğitim programlarını eğitsel çıktılar bakımından değerlendiren sınırlı sayıda çalışma olduğu görülmüştür. Bu değerlendirme çalışmaları içerisinde, 21. yüzyıl becerilerinin kazandırılması ve geliştirilmesine yönelik çalışmaların da sayıca oldukça az oluşu dikkati çekmektedir (Andersson \& Reimers, 2009; Ray \& McCoy, 2000; Delialioğlu, Öncü ve Çakır, 2008). Bu nedenle BT sertifika eğitim programlarının kapsam olarak iyileştirilmesi ve etkisinin ölçülmesi için değerlendirme çalışmalarına ihtiyaç duyulmakta ve teknoloji ağırlıklı sertifika eğitim programlarında cinsiyete bağlı dezavantajlı grupların oluşup oluşmadığının belirlenmesi gerektiği düşünülmektedir.

\section{Çalışmanın Amacı}

Bu çalışma, mesleki ve teknik liselerin bilişim ve elektrik-elektronik teknolojileri bölümlerinde öğrenim görmekte olan, Cisco sertifika (CCNA) programına katılan ve katılmayan öğrencileri 21. yüzyıl becerileri açısından karşılaştırmayı ve sertifika programına katılan öğrenciler arasında 21. yüzyıl beceri düzeylerinin cinsiyete bağlı dezavantajlı grupların oluşup oluşmadığını belirlemeyi amaçlamaktadır. Bu amaç doğrultusunda aşağıdaki araştırma sorularına yanıt aranmaya çalışılmışıtır:

1. Cisco sertifika programına katılan ve katılmayan öğrenciler arasında 21. yüzyıl beceri düzeyleri bakımından anlamlı fark var mıdır?

2. Cisco sertifika programına katılan öğrencilerin 21. yüzyıl beceri düzeylerinde cinsiyete göre anlamlı fark var midır?

\section{Yöntem}

$\mathrm{Bu}$ çalışmada nicel araştırma yöntemlerinden biri olan yarı deneysel araştırma modeli kullanılmıştır. Gerçek deneysel desende katılımcılar tamamen rastgele seçilirken yarı deneysel desende araştırmacı var olan gruplarda farklı koşulları inceler ve bireyleri rastgele seçemez (Plano Clark, \& Creswell, 2015).

$\mathrm{Bu}$ çalışmada mesleki ve teknik liselerin bilişim ve elektrik-elektronik teknolojileri bölümlerinde öğrenim görmekte olan, Cisco sertifika (CCNA) programına katılan ve katılmayan öğrencilerin 21. yüzyıl beceri düzeyleri karşılaştırılarak, sertifika programına kattlan öğrenciler arasında 21. yüzyıl beceri düzeylerinin cinsiyete bağlı etkileri değerlendirilmiştir. Araşturmada bağımsız değişkenlerin (katılım durumu ve cinsiyet) bağımlı değişken (21. yüzyıl becerileri) üzerindeki etkisi incelendiğinden dolayı deneysel desenin kullanılmasına karar verilmiştir.

\section{Bağlam}

$\mathrm{Bu}$ çalışma, Cisco Networking Academy işbirliği ile mesleki ve teknik lise öğrencilerine CCNA eğitimi verilmesini kapsamaktadır. Cisco Networking Academy, dünya genelinde ağ ve internet teknolojileri eğitimi sağlamak amacıyla kurulmuş bir topluluktur. Akademi, 1997'de kuruluşundan bu yana 180'den fazla ülkede, 10.400'den fazla eğitim kurumuna ulaşmıstır (Netacad, 2018).

2007 yllında Milli Eğitim Bakanlı̆̆1 (MEB) bünyesinde bulunan Eğitim Teknolojileri Genel Müdürlüğ̈̈ (günümüzdeki adıyla 'Yenilik ve Eğitim Teknolojileri Genel Müdürlüğü’), tüm mesleki ve teknik eğitim liselerinde Bilişim Teknolojilerinin Temelleri (BT'T) ve CCNA derslerinin eğitimi ve yayma faaliyetleri için Ankara'da bir eğitim programı başlatmışır. Eğitim alanları: Bilgi teknolojileri ve elektrik/elektronik olan öğretmenler, görev yaptıkları illerde BTT ve CCNA eğiticileri olabilmek 
Çakır, H., Delialioğlu, Ö., \& Özgül, E. (2019). Bilgi teknolojileri sertifika eğitim programlarının 21. yüzyll becerileri açısından değerlendirilmesi. Journal of Human Sciences, 16(4), 998-1013. doi:10.14687/jhs.v16i4.5704

amacıyla Ankara'daki eğitim programına davet edilmiştir. Eğitim programı sonunda programı başarıyla tamamlayan öğretmenlerle, görev yaptkkları okullarda BT'T ve CCNA kurslanı açarak bu alanda öğrencilerin yetiştirilmesi sağlanmıştır. BT'T ve CCNA dersleri genellikle mesleki ve teknik liselerin bilişim ve elektrik-elektronik teknolojileri bölümlerinde öğretilmektedir. Eğitim müfredatı MEB tarafindan merkezi olarak geliştirilmiş ve onaylanmış olduğundan öğretmenler yerleşik programa göre dersleri yürütmektedirler.

\section{Çalışma Grubu}

Araştırmanın evrenini, 2012-2013 eğitim-öğretim yllında Türkiye'deki mesleki ve teknik liselerin bilişim ve elektrik-elektronik teknolojileri bölümlerinde öğrenim gören öğrenciler oluşturmaktadır. 2011-2012 eğitim-öğretim yllı itibariyle Türkiye'de resmî olarak 4794 mesleki ve teknik lise bulunmakta ve yaklaşı 1,55 milyon öğrenci eğitim-öğretim faaliyetlerinden yararlanmaktadır (MEB, 2012). Yine bu liselerin çoğunluğunda bilişim ve elektrik-elektronik teknolojileri bölümlerinin bulunduğu görülmektedir. Çalışmaya bu okullar arasından 95 okul katılım göstermiş ve öğrenci grupları (Cisco sertifika programına katılan ve katılmayan) bilgisi Tablo 2'de verilmiştir.

Tablo 2. Çalışmaya Katılım Oranları

\begin{tabular}{lccc|ccc} 
& \multicolumn{2}{c|}{ Cisco Eğitimi Alan Grup } & \multicolumn{3}{c}{ Cisco Eğitimi Almayan Grup } \\
& $\begin{array}{c}\text { Dersi alan } \\
\text { (Toplam) }\end{array}$ & $\begin{array}{c}\text { Çalışmaya } \\
\text { Katılan }\end{array}$ & $\begin{array}{c}\text { Geri } \\
\text { Dönüş } \\
\text { Oranı }\end{array}$ & $\begin{array}{c}\text { Karşlaştırma } \\
\text { Grubu }\end{array}$ & $\begin{array}{c}\text { Çalışmaya } \\
\text { Katılan }\end{array}$ & $\begin{array}{c}\text { Geri } \\
\text { Dönüş } \\
\text { Oranı }\end{array}$ \\
\hline $\begin{array}{l}\text { Öğrenci } \\
\text { Sayısı }\end{array}$ & 1178 & $\mathbf{6 9 5}$ & $\% 59$ & $1175^{*}$ & $\mathbf{7 5 8}$ & $\% 0645$ \\
\hline
\end{tabular}

*: Yaklaşık bir sayıyı göstermektedir

Tablo 2'de çalışmaya katılım durumları incelendiğinde Cisco sertifika programına katılan 1178 öğrenciden 695’ine, Cisco dışındaki yaklaşık 1175 öğrenciden ise 758'ine ulaşılmış olup toplamda 1453 öğrenci çalışmaya katılmıştır. Çalışmaya katulım genel olarak lise 10. ve 11. sınıflarında öğrenim görmekte olan öğrencilerden oluşmaktadır. Bu çalışmada Cisco sertifika programına katılan grup deney grubu, sertifika programına katılmayan grup ise karşılaştırma grubu olarak belirlenmiştir.

Karşılaştırma grubu, aynı okul, aynı bölüm, aynı sınıf düzeyinde ve Cisco eğitimine katılmayan öğrencilerden oluşmalıdır. Ancak, değişen okul büyüklükleri ve kursların uygulanma zamanlarındaki farklılıklardan dolayı ideal karşılaştırma grubunu oluşturmak her zaman mümkün olmamaktadır. $\mathrm{Bu}$ nedenle karşılaştırma grubunu belirlemek için araştırmacılar tarafindan bir yöntem geliştirilmiştir. Öncelik sırasına göre, bir karşılaştırma grubu belirlemek için aşağıdaki kriterler kullanılmıştır:

1. Farklı şube, aynı sınıf, aynı bölüm, aynı okul, aynı bölge (istenilen).

2. Aynı sınıf, benzer bölüm, aynı okul, aynı bölge.

3. Aynı sınıf, aynı bölüm, farklı okul, aynı bölge.

4. Aynı sınıf, benzer bölüm, farklı okul, aynı bölge.

5. Aynı sınıf, aynı bölüm, farklı okul, benzer bölge.

Karşılaştırma grubunun oluşturulma süreci araştırma ekibi için oldukça güç gerçekleşmiştir. Bilişim teknolojileri bölümlerindeki öğrenci sayılarının bazı okullarda çok az olması ayrıca teknolojiye erişim bakımından bazı okullarda yaşanan sınırlılıklar bu süreci oldukça zorlaştırmıştır. 
Çakır, H., Delialioğlu, Ö., \& Özgül, E. (2019). Bilgi teknolojileri sertifika eğitim programlarının 21. yüzyıl becerileri açısından değerlendirilmesi. Journal of Human Sciences, 16(4), 998-1013. doi:10.14687/jhs.v16i4.5704

Tablo 3. Cinsiyete Göre Çalıșmaya Katılım Oranları

\begin{tabular}{lcc|cc} 
& \multicolumn{2}{c|}{ Cisco Eğitimi Alan Grup } & \multicolumn{2}{c}{ Karşılaştırma Grubu } \\
& $\mathbf{N}$ & $\mathbf{0}$ & $\mathbf{N}$ & $\mathbf{\%}$ \\
\hline Kadın & 198 & 28.5 & 199 & 26.3 \\
Erkek & 497 & 71.5 & 559 & 73.7 \\
\hline Toplam & $\mathbf{6 9 5}$ & 100 & $\mathbf{7 5 8}$ & 100
\end{tabular}

Tablo 3’te görüldüğü gibi, çalışmaya katılan öğrencilerin çoğunluğu (her iki grup içinde) erkek öğrencilerden (1056 kişi, \%72,7) oluşmaktadır. Mesleki ve teknik liselerin bilişim ve elektrikelektronik teknolojileri bölümleri genellikle erkek öğrenciler tarafindan tercih edildiği bilinmektedir. Bu çalışmada da erkek öğrencilerin kattlım oranları bu durumu destekler niteliktedir.

\section{Verilerin Toplanması}

Araştırmada veriler, araştırmacılar tarafindan bir proje kapsamında geliştirilen ölçme aracı aracıllğıyla toplanmıştır. Bu ölçme aracı, çalışmaya katılan öğrencilere (Cisco ve karşılaştırma grubunda) çevrimiçi olarak uygulanan bir ankettir. Anket; açı ve kapalı uçlu, çoktan seçmeli soruların yanı sıra likert tipi 5'li derecelendirme sorularından oluşan kapsamlı bir ölçme aracıdır.

Çalışmanın yürütüldüğü her okulda, ölçme aracının uygulanabilirliğini takip etmek amacıyla bir öğretmen görevlendirilmiştir. Öğretmen, öğrencilere çalışma hakkında bilgiler vererek anketin doldurulması için gerekli yönlendirmelerde bulunmuştur. Çalışmaya katılan okullarda bilgisayar laboratuvarları kullanılarak öğrencilerin anketin doldurulacağı çevrimiçi alana (Cisco tarafindan oluşturulan sisteme) giriş yapmaları sağlanmıştır. Sisteme giriş yapan her bir öğrenci için sistem tarafindan eşsiz bir kimlik numarası atanarak, eğitimin sonuna kadar gerekli görülen durumlarda kullanılmasına yönelik öğrencilerin kişisel e-posta adreslerinin sisteme girilmesi istenmiştir.

Cisco eğitim programı ders saatleri süresince öğrencilerin ölçme aracını doldurmalarını sağlamak amacıyla, öğretmenlere periyodik olarak e-postalar ile hatırlatmalar yapılmıştır. Buna ek olarak öğretmenlerle telefon görüşmeleri yoluyla yakın temas kurulmaya çalışlmış ve olası aksaklıklar (teknik sorunlar) giderilmeye çalışılmıştır. Ayrıca ölçme aracının uygulanması için tüm ögretmenlere olası uygulama zamanları hakkında bilgiler verilmiştir.

\section{Veri Toplama Araçları}

Araştırmacılar tarafından bir proje kapsamında geliştirilen ölçme aracı, öğrencilerin demografik özellikleri, 21. yüzyıl becerileri, kendi eğitim alanlarına dair bilgileri, mezuniyet sonrası görüşleri ve verilen Cisco eğitiminin etkililiğine dair bilgileri elde etmeye yönelik toplam 92 soru ve beş bölümden oluşan kapsamlı bir anketten oluşmaktadır. Geliştirilen bu ölçme aracında çalışmanın konusu gereği sadece öğrencilerin demografik bilgilerinin ve becerilerinin yer aldığı bölümlere odaklanılmış, diğer bölümlerden elde edilen veriler kapsam dışı bırakılmıştır.

$\mathrm{Bu}$ çalışma kapsamında geliştirilen ölçme aracında öğrencilerin bilgi, beceri ve deneyimleri bakımından ele alınan 21. yüzyıl becerileri: Akademik öz-yeterlik, Bilgi okuryazarlığı, Takım çalışması, Problem çözme, Yaşam boyu öğrenme, Çalışma öz-yeterliği, Teknolojiye karşı tutum ve Kariyer öz-yeterliği olarak belirlenerek, her bir beceri alanı aşağıda kısaca açıklanmıştır.

Akademik öz-yeterlik: Kişinin öğrenim hayatı boyunca almış olduğu herhangi bir derse, çalışmış olduğu konuya, çözmüş olduğu test gibi akademik görevlere dair kendi performanslarını görme ve bu performansın iyileştirilmesine yönelik geliştireceği strateji, inanç, tutum ve davranışları kapsamaktadır (Zimmerman, 1995; Wood \& Locke, 1987).

Bilgi okuryazarlyğt Bir bilgiye ulaşma ve o bilginin ne zaman gerekli olduğunun farkına varmayı, o bilgiyi çeşitli biçimlerde ele almayı, doğru bir şekilde değerlendirebilmeyi ve etkili bir şekilde kullanabilme ve iletebilme süreçlerini kapsayan becerileri kapsamaktadır (Eisenberg, 2008). 
Çakır, H., Delialioğlu, Ö., \& Özgül, E. (2019). Bilgi teknolojileri sertifika eğitim programlarının 21. yüzyıl becerileri açısından değerlendirilmesi. Journal of Human Sciences, 16(4), 998-1013. doi:10.14687/jhs.v16i4.5704

Takam çalışmast: Belli bir topluluğa ait kişilerin ulaşılması beklenen bir amaç doğrultusunda sahip oldukları bilgi, beceri ve deneyimlerinin bir araya getirilmesi, bilgi alısverişinde bulunulması ve iş paylaşımı süreçlerini kapsamaktadır (Trilling \& Fadel, 2009).

Problem çözme: Kişinin eğitimsel, mesleki ve günlük yaşamda karşlaşttğı bir soruna yönelik; o sorunun ortaya çıkma nedenlerini belirleme, olası çözüm yollarını saptama, hangi yöntemi kullanacağına karar verme süreçlerini kapsayan başka bir deyişle eleştirel düşünme becerilerinin bütünüdür (Heppner, Witty \& Dixon, 2004).

Yaşam boyu öğrenme: Öğrenme, birey için nerede veya ne zaman olduğuna bakılmaksızın gerçekleşebilen bir olgudur. Yaşam boyu öğrenme becerisi, bireyin herhangi bir şeyi öğrenmeye karşı isteklilik durumunu, merak düzeyini, yeni bilgiye karşı tutumu ve davranışlarını kapsamaktadır. Yaşam boyu öğrenmeye karşı daha olumlu tutum gösteren öğrenciler, öğrenmeye devam etme, daha çok kendine yönelme ve daha fazla özgüvene sahip olma eğilimindedir (Crombie \& Abarbanel, 2000).

Çalışma öz-yeterliği: Kişinin yapmakla sorumlu olduğu işiyle ilgili; zaman yönetimini, süreç içindeki organizasyonunu, üretkenlik ve işbirliği gibi süreçleri kapsayan becerilerin bütünüdür (Hodge \& Lear, 2011).

Teknolojiye karşı tutum: Bireyin hem kişisel özellikleri (öz-yeterlik algıları, tutum, cinsiyet, yaş vb.) hem de dışsal faktörler (daha önceki teknolojiden haberdar olma ve kullanım durumu) teknolojiyi kullanma konusundaki kararını ve tutumunu etkilemektedir (Lambert \& Gong, 2010). Kişinin hayatını kolaylaştırmak amacıyla yeni teknolojik araçları tanıma, bu teknolojileri nasıl kullanılacağını bilme ve kendi amaçları doğrultusunda organize etme süreçlerini kapsamaktadır.

Kariyer öz-yeterliğ̈: Kişinin sahip olduğu yeteneklere uygun iş veya iş kesimlerini belirlemesi ve kendini yönlendirmesi, bu işler hakkında bilgi edinmesi, gelecekte bu iş kesimindeki olası istihdam olanakları ve ortalama gelir durumları hakkında bilgi edinmesi süreçlerini ve girissimcilik, liderlik ve sorumluluk gibi beceri alanlarını kapsamaktadır (Trilling \& Fadel, 2009).

Geliştirilen ölçme aracının kapsam geçerliğinin sağlanması amacıyla hazırlanan sorular, konu alan uzmanları tarafindan oluşan bir panelde gözden geçirildikten sonra lise öğrencileri üzerinde bir pilot uygulama gerçekleştirilmiştir. Ölçeğin pilot uygulaması sonucunda iç tutarlılık katsayıları hesaplanmış ve tüm yapılar için Cronbach alfa değerleri Tablo 4'te yer verilmiştir. Ayrıca aynı yapı altında gruplandırılmış öğeleri tanımlamak için faktör analizi yapılmış ve ilgisiz olduğu belirlenen maddeler araştırmadan çıkarılmıştır. Ölçme aracında yer alan soruların faktör analizi sonucuna göre 8 farklı yapıya ulaşılmıştır.

Tablo 4. 21. Yüzyıl Becerileri Ölçeğine Göre Alt Boyutlanın Güvenilirlik Katsayılanı

\begin{tabular}{lcl}
\hline Alt Boyutlar & $\begin{array}{c}\text { Güvenilirlik } \\
\text { Katsayısı }(\alpha)\end{array}$ & $\begin{array}{l}\text { Madde } \\
\text { Sayıs1 }\end{array}$ \\
\hline Akademik öz-yeterlik & .93 & $13(32-44)$ \\
Bilgi okuryazarlı̆̆ & .91 & $6(45-50)$ \\
Takım çalş̧ması & .91 & $6(51-56)$ \\
Problem çözme & .90 & $7(57-63)$ \\
Yaşam boyu öğrenme & .88 & $5(64-68)$ \\
Çalşsma öz-yeterliği & .91 & $6(69-74)$ \\
Teknolojiye karşı tutum & .88 & $4(75-78)$ \\
Kariyer öz-yeterliği & .94 & $10(79-88)$ \\
\hline
\end{tabular}


Çakır, H., Delialioğlu, Ö., \& Özgül, E. (2019). Bilgi teknolojileri sertifika eğitim programlarının 21. yüzyıl becerileri açısından değerlendirilmesi. Journal of Human Sciences, 16(4), 998-1013. doi:10.14687/jhs.v16i4.5704

Tablo 4'te yer alan Cronbach alfa değerlerinin .88 ile .94 arasında değiştiği görülmektedir. Güvenirlik katsayısı $(\alpha)$ değerinin .70 ve üzerinde olması ölçeğin güvenilir olduğunu (Sipahi, vd., 2008) bu yönüyle ele alındığında ölçme aracının yüksek güvenirliğe sahip olduğu görülmektedir.

\section{Verilerin Analizi}

Araştırmacılar tarafından hazırlanan ölçme aracı geçerlik, güvenirlik hesaplamalarının yapılmasından sonra deney ve karşılaştırma grubu öğrencilerine ayrı ayrı uygulanmıştır. Araştırmada elde edilen veriler betimsel ve ilişkisel istatistik yöntemleri ile analiz edilmiştir.

Araştırma verilerinin yorumlanmasında frekans, yüzde, aritmetik ortalama $(\mathrm{X})$, standart sapma (S), serbestlik derecesi (sd) hesaplanmış ve ikili değişkenler için "Bağımsız örneklem t testi" kullanılmıştır. T testinin uygunluğu için verilerin normal dağıllım gösterip göstermediği belirlemek üzere Kolmogorov-Smirnov (K-S) testi uygulanmıştr. Tabachnick ve Fidell (2013), verilerin normal dağılım gösterebilmeleri için çarpıklık (skewness) ve basıklı (kurtosis) değerlerinin -1.5 ile +1.5 arasında değişmesi gerektiğini kabul etmektedir. K-S normallik testi sonucuna göre verilerin tamamı normallik değerleri arasında olduğu belirlenmiştir. Yapılan analizler sırasında Levene istatistiği sonuçlarının gruplar ya da değişkenler arasındaki farkın anlamlı çıkması durumunda ise parametrik olmayan t sınaması Mann-Whitney $U$ testi uygulanmıştur. Verilerin analizinde anlamlılık düzeyi (p) 0.05 olarak kabul edilmiştir.

\section{Bulgular}

Araştırmanın bu bölümünde "Cisco sertifika programına katılan ile katılmayan öğrenciler arasında 21. yüzyıl beceri düzeyleri bakımından anlamlı fark var mıdır?" sorununa cevap aranmıştır. Ayrıca Cisco sertifika programına katılan grup içerisinde 21. yüzyıl becerilerinin cinsiyete bağlı değişim etkisi incelenerek herhangi bir farkın olup olmadığı belirlenmeye çalışılmıştır.

Cisco eğitimine katılan deney grubu ile karşılaştırma grubunun 21. yüzyıl beceri düzeylerine göre betimsel analizi yapılarak her bir beceri düzeyine göre almış oldukları puan ve istatistiki bilgiler Tablo 5'te verilmiştir.

Tablo 5. Katılımcıların 21. Yüzyıl Beceri Puanlarına Göre Karşılaştırılması

\begin{tabular}{|c|c|c|c|c|c|c|c|}
\hline & & $\mathbf{N}$ & $\mathbf{X}$ & $\mathbf{S}$ & sd & $\mathbf{t}$ & $\mathrm{p}$ \\
\hline \multirow{2}{*}{$\begin{array}{l}\text { Akademik } \\
\text { yeterlik }\end{array}$} & Cisco Grubu & 740 & 3.53 & .68 & \multirow{2}{*}{1542} & \multirow{2}{*}{2.787} & \multirow{2}{*}{$.005^{*}$} \\
\hline & Karşılaşturma Grubu & 800 & 3.43 & .68 & & & \\
\hline \multirow{2}{*}{ Bilgi okuryazarlığ1 } & Cisco Grubu & 737 & 3.72 & .70 & \multirow{2}{*}{1522} & \multirow{2}{*}{2.234} & \multirow{2}{*}{$.026^{*}$} \\
\hline & Karşılaşturma Grubu & 787 & 3.63 & .75 & & & \\
\hline \multirow{2}{*}{ Takım çalışması } & Cisco Grubu & 739 & 4.12 & .78 & \multirow{2}{*}{1517.86} & \multirow{2}{*}{6.356} & \multirow{2}{*}{$.000^{*}$} \\
\hline & Karşılaştırma Grubu & 783 & 3.85 & .86 & & & \\
\hline \multirow{2}{*}{ Problem çözme } & Cisco Grubu & 741 & 3.86 & .65 & \multirow{2}{*}{1523.42} & \multirow{2}{*}{4.576} & \multirow{2}{*}{$.000^{*}$} \\
\hline & Karşılaşturma Grubu & 791 & 3.69 & .75 & & & \\
\hline \multirow{2}{*}{$\begin{array}{l}\text { Yaşam } \\
\text { öğrenme }\end{array}$} & Cisco Grubu & 742 & 4.07 & .68 & \multirow{2}{*}{1525.71} & \multirow{2}{*}{3.530} & \multirow{2}{*}{$.000^{*}$} \\
\hline & Karşılaşturma Grubu & 793 & 3.93 & .78 & & & \\
\hline \multirow{2}{*}{ Çalışma öz-yeterliği } & Cisco Grubu & 714 & 3.85 & .65 & \multirow{2}{*}{1491} & \multirow{2}{*}{1.532} & \multirow{2}{*}{.126} \\
\hline & Karşılaşturma Grubu & 779 & 3.80 & .69 & & & \\
\hline \multirow{2}{*}{$\begin{array}{l}\text { Teknolojiye } \\
\text { tutum }\end{array}$} & Cisco Grubu & 713 & 3.89 & .71 & \multirow{2}{*}{1486} & \multirow{2}{*}{-1.311} & \multirow{2}{*}{.190} \\
\hline & Karşılaşturma Grubu & 775 & 3.94 & .75 & & & \\
\hline \multirow{2}{*}{ Kariyer öz-yeterliği } & Cisco Grubu & 713 & 3.86 & .62 & \multirow{2}{*}{1488} & \multirow{2}{*}{.609} & \multirow{2}{*}{.543} \\
\hline & Karşılaşturma Grubu & 777 & 3.84 & .67 & & & \\
\hline
\end{tabular}

$* \mathrm{p}<0.05$ 
Çakır, H., Delialioğlu, Ö., \& Özgül, E. (2019). Bilgi teknolojileri sertifika eğitim programlarının 21. yüzyıl becerileri açısından değerlendirilmesi. Journal of Human Sciences, 16(4), 998-1013. doi:10.14687/jhs.v16i4.5704

Tablo 5 incelendiğinde akademik öz-yeterlik beceri düzeyleri bakımından Cisco grubu öğrencileri karşllaştırma grubu öğrencilerine göre anlamlı farkl1lı göstermektedir, $t(2.787)=1542$, $\mathrm{p}<.05$. Cisco grubu öğrencilerinin $(\mathrm{X}=3.53)$ akademik öz-yeterlik beceri düzeyleri karşılaştırma grubuna $(X=3.43)$ oranla daha yüksek olduğu görülmektedir. Akademik öz-yeterlik, öğrencinin yeni bir içeriği öğrenme üzerindeki genel yeteneğini ve almış oldukları derslerdeki yüksek başarı notuna sahip olma durumunu göstermektedir. Bu bağlamda Cisco grubu öğrencilerinin almış oldukları derslerde karşılaştırma grubuna göre daha başarılı oldukları görülmektedir.

Bilgi okuryazarlığı beceri düzeyleri bakımından Cisco grubu öğrencileri karşılaştırma grubu öğrencilerine göre anlamlı farklllik göstermektedir, $\mathrm{t}(2.234)=1522, \mathrm{p}<.05$. Cisco grubu ögrencilerinin $(X=3.72)$ bilgi okuryazarlığı beceri düzeyleri karşılaştırma grubuna $(X=3.63)$ oranla daha yüksek olduğu görülmektedir. Öğrencinin bilgiye ulaşma ve elde ettiği bilgiyi etkili bir şekilde kullanabilme yeteneği olarak görülen bu beceri düzeyinde Cisco grubu öğrencilerinin yeni bir bilgiye ulaşma, o bilgiyi kullanma ve değerlendirme noktasında karşılaştırma grubuna göre daha yetenekli oldukları sonucuna ulaşılmıştır.

Takım çalışması beceri düzeyleri bakımından Cisco grubu öğrencileri karşılaştırma grubu öğrencilerine göre anlamlı farklllık göstermektedir, $\mathrm{t}(6.356)=1517.86, \mathrm{p}<.05$. Cisco grubu öğrencilerinin $(X=4.12)$ takım çalışması beceri düzeyleri karşılaştırma grubuna $(X=3.85)$ oranla oldukça yüksek olduğu görülmektedir. Öğrencilerin belli bir amaç doğrultusunda birlikte hareket etmesi, görev paylaşımı ve fikir alışverişinde bulunması olarak ifade edilen bu beceri alanında Cisco grubu öğrencilerinin karşılaştırma grubuna göre takım çalışmasında oldukça yetenekli oldukları görülmektedir.

Problem çözme beceri düzeyleri bakımından Cisco grubu öğrencileri karşılaştırma grubu öğrencilerine göre anlamlı farkllık göstermektedir, $\mathrm{t}(4.576)=1523.42, \mathrm{p}<.05$. Cisco grubu öğrencilerinin $(X=3.86)$ problem çözme beceri düzeyleri karşılaştırma grubuna $(X=3.69)$ oranla oldukça yüksek olduğu görülmektedir. Öğrencilerin karşılaştı̆̆1 sorunlara yönelik sorunun ortaya çıkma nedeni saptama ve bu soruna yönelik geliştirmiş oldukları çözüm yolları becerisi bakımından Cisco grubu öğrencilerinin karşılaştırma grubuna göre oldukça yetenekli oldukları sonucuna ulaşılmıştır.

Yaşam boyu öğrenme beceri düzeyleri bakımından Cisco grubu öğrencileri karşılaştırma grubu öğrencilerine göre anlamlı farklılık göstermektedir, $\mathrm{t}(3.530)=1525.71, \mathrm{p}<.05$. Cisco grubu öğrencilerinin $(X=3.72)$ yaşam boyu öğrenme beceri düzeyleri karşlaştırma grubuna $(X=3.63)$ oranla oldukça yüksek olduğu görülmektedir. Öğrencinin bir şeyi öğrenmeye karşı isteklilik durumu, merak düzeyi ve yeni bilgiye karşı tutum ve davranışlarını kapsayan bu beceri alanında Cisco grubu öğrencilerinin karşılaştırma grubuna göre oldukça yetenekli oldukları görülmektedir.

Çalışma öz-yeterliği beceri düzeyleri bakımından Cisco grubu öğrencileri ile karşılaştırma grubu arasında anlamlı farklılık görülmemektedir, $\mathrm{t}(1.532)=1491, \mathrm{p}>.05$. Cisco grubu öğrencilerinin çalışma öz-yeterliği beceri düzeyleri $(X=3.85)$ karşlaştırma grubuna $(X=3.80)$ göre kısmen fazla olsa da anlamlılık açısından her iki grubun benzer düzeyde oldukları görülmektedir. Öğrencilerin yapmakla sorumlu olduğu görevleri ile ilgili olarak süreç içerisinde göstermiş oldukları ilgi, performans ve işbirliği gibi yetenekleri bakımından her iki grubun benzer özelliklere sahip oldukları sonucuna ulaşılmışır.

Teknolojiye karşı tutum düzeyleri bakımından Cisco grubu öğrencileri ile karşılaştırma grubu arasında anlamlı farklılık görülmemektedir, $\mathrm{t}(-1.311)=1486, \mathrm{p}>.05$. Karşılaştırma grubunun teknolojiye karşı tutum düzeyleri $(X=3.94)$ Cisco grubu öğrencilerine $(X=3.89)$ göre kısmen fazla olsa da anlamlılık açısından her iki grubun benzer düzeyde oldukları görülmektedir. Öğrencilerin kendi amaçları doğrultusunda yeni teknolojileri kullanma konusundaki karar ve tutumları açısından her iki grubun benzer özelliklere sahip oldukları sonucuna ulaşılmıştır.

Kariyer öz-yeterliği beceri düzeyleri bakımından Cisco grubu öğrencileri ile karşılaştırma grubu arasında anlamlı farklılık görülmemektedir, t(.609)=1488, p>.05. Cisco grubu öğrencilerinin kariyer öz-yeterliği beceri düzeyleri $(X=3.86)$ karşılaştırma grubu $(X=3.84)$ ile benzer düzeyde 
Çakır, H., Delialioğlu, Ö., \& Özgül, E. (2019). Bilgi teknolojileri sertifika eğitim programlarının 21. yüzyıl becerileri açısından değerlendirilmesi. Journal of Human Sciences, 16(4), 998-1013. doi:10.14687/jhs.v16i4.5704

oldukları görülmektedir. Öğrencilerin sahip olduğu yeteneklere uygun iş veya iş kesimlerini belirleme becerisi olarak ifade edilen bu beceri alanında her iki grup arasında anlamlı farkın olmadığ1 görülmektedir.

Araştırmanın bir diğer sorusu olan Cisco sertifika programına katılan grup içerisinde 21. yüzyıl becerilerinin cinsiyete bağlı değişim etkisi incelerek öğrencilerin her bir beceri düzeyine göre almış oldukları puan ve istatistiki bilgiler Tablo 6'da verilmiştir.

Tablo 6. Cisco Eğitimine Katılan Öğrencilerin 21. Yüzyıl Beceri Puanlarının Cinsiyete Göre Karşılaştırılması

\begin{tabular}{|c|c|c|c|c|c|c|c|}
\hline & & $\mathbf{N}$ & $\mathbf{x}$ & $\mathbf{S}$ & sd & $\mathbf{t}$ & $\mathrm{p}$ \\
\hline \multirow{2}{*}{ Akademik öz-yeterlik } & Kadin & 194 & 3.57 & .56 & \multirow{2}{*}{439.46} & \multirow{2}{*}{1.040} & \multirow{2}{*}{.299} \\
\hline & Erkek & 469 & 3.51 & .70 & & & \\
\hline \multirow{2}{*}{ Bilgi okuryazarlığ1 } & Kadin & 193 & 3.66 & .61 & \multirow{2}{*}{417.47} & \multirow{2}{*}{-1.704} & \multirow{2}{*}{.089} \\
\hline & Erkek & 463 & 3.76 & .71 & & & \\
\hline \multirow{2}{*}{ Takım çalışması } & Kadin & 194 & 4.08 & .69 & \multirow{2}{*}{424.45} & \multirow{2}{*}{-.746} & \multirow{2}{*}{.456} \\
\hline & Erkek & 465 & 4.13 & .82 & & & \\
\hline \multirow{2}{*}{ Problem çözme } & Kadin & 193 & 3.80 & .59 & \multirow{2}{*}{658} & \multirow{2}{*}{-1.593} & \multirow{2}{*}{.112} \\
\hline & Erkek & 467 & 3.89 & .68 & & & \\
\hline \multirow{2}{*}{ Yaşam boyu öğrenme } & Kadin & 194 & 3.98 & .63 & \multirow{2}{*}{659} & \multirow{2}{*}{-2.159} & \multirow{2}{*}{$.031 *$} \\
\hline & Erkek & 467 & 4.11 & .69 & & & \\
\hline \multirow{2}{*}{ Çalışma öz-yeterliği } & Kadin & 193 & 3.76 & .57 & \multirow{2}{*}{664} & \multirow{2}{*}{-2.214} & \multirow{2}{*}{$.027 *$} \\
\hline & Erkek & 473 & 3.88 & .64 & & & \\
\hline \multirow{2}{*}{ Teknolojiye karşı tutum } & Kadin & 192 & 3.69 & .68 & \multirow{2}{*}{663} & \multirow{2}{*}{-4.649} & \multirow{2}{*}{$.000^{*}$} \\
\hline & Erkek & 473 & 3.97 & .69 & & & \\
\hline \multirow{2}{*}{ Kariyer öz-yeterliği } & Kadin & 192 & 3.77 & .56 & \multirow{2}{*}{663} & \multirow{2}{*}{-2.393} & \multirow{2}{*}{$.017^{*}$} \\
\hline & Erkek & 473 & 3.90 & .62 & & & \\
\hline
\end{tabular}
$* \mathrm{p}<0.05$

Tablo 6 incelendiğinde akademik öz-yeterlik beceri düzeyleri bakımından erkek öğrenciler ile kadın öğrenciler arasında anlamlı farklılık görülmemektedir, $\mathrm{t}(1.040)=439.46, \mathrm{p}>.05$. Cisco eğitimine katılan grup içerisinde erkek öğrenciler $(X=3.51)$ ile kadın öğrencilerin $(X=3.57)$ akademik özyeterlik beceri düzeyleri bakımından benzer düzeyde oldukları görülmektedir. Cisco eğitimine katılan öğrencilerin bildirdikleri kümülatif not ortalamalarının cinsiyete bağlı etkisi incelendiğinde kadın öğrencilerin not ortalamalarının erkek öğrencilere $\left(X_{K}-X_{E}=0.06\right)$ göre kısmen fazla olduğu görülse de anlamlılık ( $\mathrm{p}>$.05) açısından çok büyük bir farkın olmadığı, her iki cinsiyet grubu arasında akademik öz-yeterlikleri bakımından benzer olduğu sonucuna ulaşılmıştır.

Bilgi okuryazarlığı beceri düzeyleri bakımından erkek öğrenciler ile kadın öğrenciler arasında anlamlı farklılık görülmemektedir, $\mathrm{t}(-1.704)=417.47, \mathrm{p}>.05$. Cisco eğitimine katılan grup içerisinde erkek öğrenciler $(X=3.76)$ ile kadın öğrencilerin $(X=3.66)$ bilgi okuryazarllğı beceri düzeyleri bakımından benzer düzeyde oldukları görülmektedir. Cisco eğitimine katılan öğrenciler arasında bilgiye ulaşma ve elde edilen bilginin etkili bir şekilde kullanımı olarak ifade edilen bu beceri alanında erkek öğrencilerin kadın öğrencilere $\left(X_{\mathrm{E}}-X_{\mathrm{K}}=0.1\right)$ göre kısmen yetenekli oldukları görülse de anlamlılık ( $\mathrm{p}>$.05) açısından çok büyük bir farkın olmadığ1, her iki cinsiyet grubu arasında bilgi okuryazarlığı becerilerinin benzer olduğu sonucuna ulaşılmıstır. 
Çakır, H., Delialioğlu, Ö., \& Özgül, E. (2019). Bilgi teknolojileri sertifika eğitim programlarının 21. yüzyıl becerileri açısından değerlendirilmesi. Journal of Human Sciences, 16(4), 998-1013. doi:10.14687/jhs.v16i4.5704

Takım çalışması beceri düzeyleri bakımından erkek öğrenciler ile kadın öğrenciler arasında anlamlı farklılık görülmemektedir, $\mathrm{t}(-.746)=424.45, \mathrm{p}>.05$. Cisco eğitimine katılan grup içerisinde erkek öğrenciler $(X=4.13)$ ile kadın öğrencilerin $(X=4.08)$ takım çalışması beceri düzeyleri bakımından benzer düzeyde oldukları görülmektedir. Cisco eğitimine katılan öğrencilerin birlikte hareket etme, görev paylaşımı ve fikir alışverişinde bulunma gibi yetenekleri kapsadığı bu beceri alanında erkek öğrencilerin kadın öğrencilere $\left(X_{\mathrm{E}}-X_{K}=0.05\right)$ göre kısmen yetenekli oldukları görülse de anlamlılık ( $>>$.05) açısından çok büyük bir farkın olmadığı sonucuna ulaşılmıştır.

Problem çözme beceri düzeyleri bakımından erkek öğrenciler ile kadın öğrenciler arasında anlamlı farklılık görülmemektedir, $\mathrm{t}(-1.593)=658, \mathrm{p}>.05$. Cisco eğitimine katılan grup içerisinde erkek öğrenciler $(X=3.89)$ ile kadın öğrencilerin $(X=3.80)$ problem çözme beceri düzeyleri bakımından benzer düzeyde oldukları görülmektedir. Cisco eğitimine katılan öğrencilerin karşılaştı̆ı sorunlara yönelik sorunun ortaya çıkma nedenini saptama ve bu soruna yönelik geliştirmiş oldukları çözüm yolları becerisi bakımından erkek öğrencilerin kadın öğrencilere $\left(X_{\mathrm{E}}-X_{\mathrm{K}}=0.09\right)$ göre kısmen yetenekli oldukları görülse de anlamlılık ( $\mathrm{p}>.05$ ) açısından çok büyük bir farkın olmadığı sonucuna ulaşılmıştır.

Yaşam boyu öğrenme düzeyleri bakımından erkek öğrenciler kadın öğrencilere göre anlamlı farkll1lk göstermektedir, $\mathrm{t}(-2.159)=659, \mathrm{p}<.05$. Cisco eğitimine kattlan grup içerisinde erkek öğrenciler $(X=4.11)$ yaşam boyu öğrenme düzeyleri bakımından kadın öğrencilere $(X=3.80)$ göre daha yüksek puana sahiptir. Cisco eğitimine kattlan öğrencilerin bir şeyi öğrenmeye karşı isteklilik durumu, merak düzeyi ve yeni bilgiye karşı tutum ve davranışlarının belirlendiği becerileri bakımından erkek öğrencilerin kadın öğrencilere $\left(X_{E}-X_{K}=0.31\right)$ göre yaşam boyu öğrenme becerilerinin yüksek olduğu görülmektedir.

Çalışma öz-yeterliği düzeyleri bakımından erkek öğrenciler kadın öğrencilere göre anlamlı farklılık göstermektedir, $\mathrm{t}(-2.214)=664, \mathrm{p}<.05$. Cisco eğitimine kattlan grup içerisinde erkek öğrenciler $(X=3.88)$ çalışma öz-yeterliği düzeyleri bakımından kadın öğrencilere $(X=3.76)$ göre daha yüksek düzeydedir. Cisco eğitimine katılan öğrencilerin yapmakla sorumlu olduğu görevleri ile ilgili olarak süreç içerisinde göstermiş oldukları ilgi, performans ve işbirliği gibi yetenekleri bakımından erkek öğrencilerin kadın öğrencilere $\left(\mathrm{X}_{\mathrm{E}}-\mathrm{X}_{\mathrm{K}}=0.12\right)$ göre çalışma öz-yeterliği becerilerinin yüksek olduğu görülmektedir.

Teknolojiye karşı tutum düzeyleri bakımından erkek öğrenciler kadın öğrencilere göre anlamlı farkll1lk göstermektedir, $\mathrm{t}(-4.649)=663, \mathrm{p}<.05$. Cisco eğitimine kattlan grup içerisinde erkek öğrenciler $(X=3.97)$ teknolojiye karşı tutum düzeyleri bakımından kadın öğrencilere $(X=3.69)$ göre oldukça yüksek düzeydedir. Cisco eğitimine katılan öğrencilerin kendi amaçları doğrultusunda yeni teknolojileri kullanma konusundaki karar ve tutumları açısından erkek öğrencilerin kadın öğrencilere $\left(\mathrm{X}_{\mathrm{E}}-\mathrm{X}_{\mathrm{K}}=0.28\right)$ göre teknolojiye karşı tutumlarının yüksek olduğu sonucuna ulaşılmıştır.

Kariyer öz-yeterliği düzeyleri bakımından erkek öğrenciler kadın öğrencilere göre anlamlı farkll1lk göstermektedir, $\mathrm{t}(-2.393)=663, \mathrm{p}<.05$. Cisco eğitimine kattlan grup içerisinde erkek öğrenciler $(X=3.90)$ kariyer öz-yeterliği düzeyleri bakımından kadın öğrencilere $(X=3.77)$ göre daha yüksek düzeydedir. Cisco eğitimine katılan öğrencilerin sahip olduğu yeteneklere uygun iş veya iş kesimlerini belirleme becerileri bakımından erkek öğrencilerin kadın öğrencilere $\left(X_{E}-X_{K}=0.13\right)$ göre daha yetenekli oldukları, dolayısıyla erkek öğrencilerin kariyer öz-yeterliği düzeylerinin yüksek olduğu sonucuna ulaşılmıştır.

\section{Sonuç, Tartışma ve Öneri}

Bu çalışmada mesleki ve teknik liselerin bilişim ve elektrik-elektronik teknolojileri bölümlerinde öğrenim görmekte olan, Cisco sertifika (CCNA) programına katılan ve katılmayan öğrencilerin 21. yüzyıl beceri düzeyleri karşılaştırılmış ve ayrıca sertifika programına katılan öğrenciler arasında 21. yüzyıl beceri düzeylerinin cinsiyete bağlı etkileri değerlendirilmiştir. $\mathrm{Bu}$ çalışmanın sonunda aşağıdaki sonuçlara ulaşılmışırı. 
Çakır, H., Delialioğlu, Ö., \& Özgül, E. (2019). Bilgi teknolojileri sertifika eğitim programlarının 21. yüzyıl becerileri açısından değerlendirilmesi. Journal of Human Sciences, 16(4), 998-1013. doi:10.14687/jhs.v16i4.5704

Cisco sertifika programına katılan öğrencilerin 21. yüzyll beceri düzeylerinin karşılaşturma grubu öğrencilerine göre daha yüksek olduğu görülmüştür. Özellikle sertifika programını tercih eden öğrencilerin takım çalışması, problem çözme ve yaşam boyu öğrenme beceri düzeylerinin programa katılmayan öğrencilere göre oldukça yüksek olduğu sonucuna ulaşılmıstır. Yine sertifika programına katılan öğrencilerin akademik öz-yeterlik ve bilgi okuryazarlı̆̆1 becerilerinin sertifika programına katılmayan öğrencilere göre yüksek olduğu görülmektedir.

Akademik başarı, öğrencinin yeni bir içeriği öğrenme üzerindeki genel yeteneğini ifade etmektedir ve genel not ortalaması yüksek olan öğrencilerin aldıkları yeni derslerde de yüksek başarı notuna sahip olma olasılıkları diğer öğrencilere göre daha fazladır (Gray ve Jesson, 1990; Hakkinen, Kirjavainen \& Uusitalo, 2003). Cisco sertifika programına katılan öğrencilerin akademik öz-yeterlik becerilerinin programa katulmayan öğrencilere göre daha yüksek olması bu durumu destekler niteliktedir. Andersson \& Reimers (2009) tarafindan gerçekleştirilen çalışmada, BT sertifikalarına sahip lise öğrencilerinin teknik beceriler ve derse katılım durumları bakımından diğer öğrencilere göre daha fazla gelişim gösterdikleri sonucuna ulaşmışlardır. Bu çalışmada da Cisco sertifika programına katılan öğrencilerin ilgili 21. yüzyıl beceri düzeylerinin yüksek olması bu çalışma ile benzer sonuçlara ulaşıldığını göstermektedir.

2011-2012 eğitim-öğretim yllı itibariyle Türkiye'de resmî olarak 4794 mesleki ve teknik lise bulunmakta ve yaklaşık 1,55 milyon öğrencinin \%58'ini erkek öğrenciler oluşturmaktadır (MEB, 2012). Bu çalışmada sertifika programlarına katulım durumları erkeklerde daha yoğun gerçekleşmiştir. Bu durum meslek liselerine öğrenim gören öğrencilerin genelinin erkek olmasıyla açılkanabilir.

Alanyazında temel teknoloji okuryazarlığının cinsiyet üzerinde bir eşitsizlik konusu oluşturmadığını destekleyen çalışmalar bulunmaktadır. BİT okuryazarlığı konusunda kadınların teknoloji kullanım sıkllğı, algılanan BİT becerileri ve bilgisayarlara karşı genel tutumları yönünden artık erkekler kadar iyi performans sergiledikleri görülmüştür (Hohlfeld, Ritzhaupt \& Barron, 2013; Sumner \& Niederman, 2004). Bu çalışmada da kadın öğrencilerin ilgili 21. yüzyıl becerilerine sahip olma durumu bakımından erkek öğrenciler ile benzer yeteneklere sahip oldukları sonucuna ulaşılmışıtır. Ancak bilişim teknolojilerinin bir meslek eğitimi olarak verildiği durumlarda halen kadın ve erkek öğrenciler arasında eşitsizlik olduğu, bu durumun müfredattan $\mathrm{m}$, derslerin işleniş şeklinden mi yoksa kadın öğrencilerin teknolojiye bakış açısından $\mathrm{m}$ k kaynaklandığının hâlen araşturılması gereken konular arasında olduğu düşünülmektedir.

Her ne kadar BT alanında artık cinsiyetin belirleyici bir unsur olmadığı daha çok bireylerin teknik yeterlilik ve kariyer deneyimlerine odaklanıldığı ifade edilse de mevcut pozisyonlardaki erkek BT uzmanları ortalama maaşlarının kadın BT uzmanlarına göre daha fazla olduğu görülmüştür (Sumner \& Werner, 2001; Sumner \& Niederman, 2004). Bu çalışmada da kariyer farkındalığ1 düzeyleri bakımından erkeklerin kadınlara göre daha yüksek becerilere sahip oldukları görülse de BT alanında cinsiyet eşitsizliğinin ortadan kaldırılması ve BT alanında kadınların daha fazla işgücünde yer alması için teknoloji ile ilgili mesleki eğitimlerde eğitim programlarının ve eğitim yöntemlerinin çalışılması gerektiği çok açıtıt.

Son olarak BT sertifikalarının yaygınlığı göz önüne alındığında, bu sertifikaların faydalarını ortaya koymak ve var olan risklerin önemini belirlemek için daha fazla araştırmaya ihtiyaç duyulduğu düşünülmektedir.

\section{Kaynakça}

Adelman, C. (2000). A parallel universe: Certification in the information technology guild. Change, 32(3), 2029.

Andersson, D., \& Reimers, K. (2009). CIS and Information Technology Certifications: Education Program Trends and Implications. Journal of Educational Technology, 6(3), 34-41.

Bird, D. (2001). Certified paths to success. Certification Magarine.

Birleşik Devletler Çalışma Bakanlığı (2017). United States Department of Labor, Bureau of Labor Statistics. http://www.bls.gov/emp/ep table 102.htm. adresinden 20.12.2018 tarihinde erişilmiştir. 
Çakır, H., Delialioğlu, Ö., \& Özgül, E. (2019). Bilgi teknolojileri sertifika eğitim programlarının 21. yüzyıl becerileri açısından değerlendirilmesi. Journal of Human Sciences, 16(4), 998-1013. doi:10.14687/jhs.v16i4.5704

Cantor, J. (2002). Skills certifications and workforce development: Partnering with industry and ourselves. Leadership Abstracts, 15(1).

Cisco Network Academy, (2018). About us. https://www.netacad.com/about-networking-academy

Cisco Systems, Inc. (2004). Company Profile / Offices - Annual Report 2004. https://www.cisco.com/c/en/us/about/annual-reports/annual-report-2004/companyprofile/offices.html adresinden 15.12.2018 tarihinde erişilmiştir.

Clarke, B. (2001). Corporate curricula in schools: issues and implementation. Paper presented at the meeting of the Seventh World Conference on Computers in Education, Copenhagen, Denmark.

CompTIA (2017). Unauthorized third-party training sites. https://www.comptia.org/ adresinden 17.12.2018 tarihinde erişilmiştir.

Crombie, G. and Abarbanel, T. (2000). Bridging the Gender Gap in High-Technology Education, NASSP Bulletin, 84(618), 64-73.

Cuban, L. (2001). Oversold and underused: Computers in the classroom. Cambridge, MA: Harvard University Press.

Çakır, H., Delialioğlu, Ö., Dennis, A., \& Duffy, T. (2009). Technology enhanced learning environments for closing the gap in student achievement between regions: Does it work? AACE Journal, 17(4), 301315.

Dağ, F. (2011). Harmanlanmış (Karma) Öğrenme Ortamları ve Tasarımına İlişkin Öneriler. Abi Evran Unniversitesi Ë̆itim Fakïltesi Dergisi, 12(2),73-97.

Delialioğlu, Ö., Çakır, H. Bichelmeyer, B. A., Dennis, A. R. ve Duffy, T. M. (2010). Factors Impacting Adult Learner Achievement In A Technology Certificate Program On Computer Networks The Turkish Online Journal of Educational Technology (TOJET), 9. 2.

Delialioğlu, Ö., Öncü, S., \& Çakır, H. (2008). Comparison of Students' Success in an International Technology Certificate Program. Hacettepe Üniversitesi Eğitim Fakülttesi Dergisi, 35(35), 75-86.

Dennis, A., Duffy, T.M., ve Çakır, H. (2010). IT programs in high schools: Lessons the Cisco Networking Academy program. Communications of the ACM, 52(1-4).

Eisenberg, M. B. (2008). Information literacy: Essential skills for the information age. DESIDOC journal of library \& information technology, 28(2), 39.

Evans, B. P., \& Gunter, G. A. (2004). A catalyst for change: Influencing preservice teacher technology proficiency. Journal of Educational Media \& Library Sciences, 41(3), 325-336.

Gomilion, D.L. (2017). The Role of Industry Certifications in an AACSB-Accredited Institution. Information Systems Education Journal (ISEDJ) 15 (1).

Gray, J. \& Jesson, D. (1990). Estimating differences in the examination of performances. Oxford Review of Education, 16(2), 137-158.

Hakkinen, I., Kirjavainen, T., \& Uusitalo, R. (2003). School resources and student achievement revisited: New evidence from panel data. Economics of Education Review, 22(3), 329-335.

Hanson-Baldauf, D., \& Hassell, S. H. (2009). The information and communication technology competencies of students enrolled in school library media certification programs. Library \& Information Science Research, 31(1), 3-11.

Heppner, P.P., Witty, T.E., \& Dixon, W. (2004). ProblemSolving Appraisal and Human Adjustment: A Review of 20 Years of Research Using the Problem-solving Inventory, The Counseling Psychologist, 32(3), 344-428.

Hitchcock, L. (2005) Industry certification: Value, validity; and a place for SoDIS®. ACM SIGCSE Bulletin, 37 (4): 59-63.

Hodge, K. A., \& Lear, J. L. (2011). Employment Skills for 21st Century Workplace: The Gap Between Faculty and Student Perceptions. Journal of Career and Technical Education, 26(2), 28-41.

Hohlfeld, T. N., Ritzhaupt, A. D., \& Barron, A. E. (2013). Are gender differences in perceived and demonstrated technology literacy significant? It depends on the model. Educational Technology Research and Development, 61(4), 639-663.

Lambert, J., \& Gong, Y. (2010). 21st Century Paradigms for Pre-Service Teacher Technology Preparation, Computers in the Schools, 27(1), 54-70.

McGill, T., \& Dixon, M. (2003). How do IT students stay up to date with employer' skill requirements. Current Issues in IT Education (144-152). Hershey, PA: IRM Press.

Meares, C. A., \& Sargent, J. F. (2003). Education and Training for the Information Technology Workforce. Washington D.C.: U.S. Department of Commerce. 
Çakır, H., Delialioğlu, Ö., \& Özgül, E. (2019). Bilgi teknolojileri sertifika eğitim programlarının 21. yüzyıl becerileri açısından değerlendirilmesi. Journal of Human Sciences, 16(4), 998-1013. doi:10.14687/jhs.v16i4.5704

Millî Eğitim Bakanlı̆̆1 (2012). Millì Eğitim İstatistikleri Örgün Eğitim 2011-2012, http://sgb.meb.gov.tr/meb iys dosyalar/2012 12/06021046 meb istatistikleri orgun egitim 201 1 2012.pdf adresinden 04.12.2018 tarihinde erişilmiştir.

National Center for Education Statistics, (2000). Teachers' tools for the 21 st century: A report on teachers' use of technology. Erişim tarihi: Ocak, 2019, https://nces.ed.gov/pubs2000/2000102.pdf

Oliver, M., Trigwell, K. (2005). Can "Blended Learning" Be Redeemed?. E-learning, 2(1), 17-26.

Osguthorpe, R.T. \& Graham, C.R. (2003). Blended learning environments. Quarterly Revien of Distance Education, 4(3), 227-233.

Partnership for 21st Century Skills (2008). A Report and Mile Guide for 21st Century Skills. http://www.p21.org/storage/documents/P21 Report.pdf adresinden 20.11.2018 tarihinde erişilmiştir.

Plano Clark, V. L., \& Creswell, J. W. (2015). Understanding research: A consumer's guide. Upper Saddle River, NJ: Pearson Education.

Randall, M. \& Zirkle, C. (2005). Information technology student-based certification in formal education settings: Who benefits and what is needed. Journal of Information Technology Education, 4, 287-306.

Ray, C. M. \& McCoy, R. (2000). Why certification in information systems? Information Technology, Learning and Performance Journal, 18(1), 1-4.

Rossett, A., Douglis, F., \& Frazee, R. V. (2003). Strategies for building blended learning. Learning Circuits. http://facilitateadultlearning.pbworks.com/f/Blended+Learning.doc adresinden 05.01.2019 tarihinde erişilmiştir.

Sandholtz, J. H., Reilly, B., \& Haymore, J. (2004). Teachers, not technicians: Rethinking technical expectations of teacher. Teachers College Record, 106(3), 487-512.

Sing, R. R. (1991). Education For The Twenty First Century: Asia-Pacific Perspectives. Unesco Principal Regional Office For Asia and The Pacific. Bangkok.

Sipahi, B., Yurtkoru, E. S. ve Çinko, M. (2008). Sosyal bilimlerde SPSS'le veri analiž. İstanbul: Beta.

Sumner M. \& Niederman F. (2004). The Impact of Gender Differences on Job Satisfaction, Job Turnover, and Career Experiences of Information Systems Professionals, Journal of Computer Information Systems, 44(2), 29-39.

Sumner, M., \& Werner, K. (2001). The impact of gender differences on the career experiences of information systems professionals. Paper presented at the Proceedings of the 2001 ACM SIGCPR conference on Computer personnel research.

Tabachnick, B.G. \& Fidell, L.S.(2013) Using Multivariate Statistics (sixth ed.) Pearson, Boston.

The Global Knowledge (2017). 15 Top-Paying IT Certifications for 2019, https://www.globalknowledge.com/us-en/content/articles/top-paying-certifications/ adresinden 15.01.2019 tarihinde erişilmiştir.

Trilling, B., \& Fadel, C. (2009). 21st century skills: Learning for life in our times: John Wiley \& Sons.

Wood, R. E., \& Locke, E. A. (1987). The relation of self-efficacy and grade goals to academic performance. Educational and Psychological Measurement, 47,1013-1024.

Zimmerman, B. J. (1995). Self-efficacy and Educational Development. In A. Bandura (Ed.), New York: Cambridge University Press.

\section{Extended English Summary}

Introduction: Today, the need for qualified and sustainable workforce is increasing due to the use of information and communication technologies (ICT). Because of the rapid changes in computer technologies, the slow progress of traditional education and the ability to bring individuals with technical skills to the field, they have initiated their own certification programs to meet the labor force demand of the IT industry (Clarke, 2001). As a requirement of the 21st century, developed and developing countries have been carrying out some studies in order to benefit from technology in education systems and to educate individuals in order to contribute to effective use and development of these technologies. One of these studies, technology certificate programs aims to help educate, identify and recruit the qualified employees. The aspect of the traditional education system, which is insufficient to respond to today's rapidly changing needs, 
Çakır, H., Delialioğlu, Ö., \& Özgül, E. (2019). Bilgi teknolojileri sertifika eğitim programlarının 21. yüzyıl becerileri açısından değerlendirilmesi. Journal of Human Sciences, 16(4), 998-1013. doi:10.14687/jhs.v16i4.5704

makes certification programs important to ensure that individuals have access to up-to-date information.

Purpose: When the literature is examined, it is seen that there is a limited number of studies evaluating IT certificate programs in terms of learning outputs. Within these evaluation studies, it is noteworthy that there are very few studies on the development of 21 st century skills. Therefore, there is a need for evaluation studies in order to improve IT certification programs in scope and measure their impact. In addition, it is thought that the impact of gender on technology certificate programs should be determined.

This study compared 21st-century skill levels of students participating and non-participating in the Cisco certificate (CCNA) program, who are studying in the departments of informatics and electrical-electronics technologies of vocational and technical high schools. In addition, the gender-related impact of 21 st century skill levels were evaluated among students participating in the certificate program.

Methodology: In this study, it was decided to use experimental design because of the effect of independent variables (21st century skills) on dependent variable (gender). In this study, the participants in the Cisco certification program were determined as experimental group and the non-participants in the certificate program were determined as comparison group. The study included 695 students in the experimental group and 758 students in the comparison group. Participation in the study is generally composed of students studying in the 10 th and 11 th grades of high school.

The data were collected by means of a measurement tool developed by the researchers within the scope of a project. This measurement tool is an online survey for students participating in the study (Cisco and the comparison group). The survey is a comprehensive measurement tool consisting of open and closed ended questions, multiple choice questions, and 5-point likert-type scale questions. In the measurement tool, 21st century skills, which are discussed in the context of students' knowledge, skills and experiences: Academic self-efficacy, information literacy, team work, problem solving, lifelong learning, work self-efficacy, attitude towards technology and career self-efficacy were determined.

Finding and Discussion: According to the findings obtained from the study, the students of Cisco group have higher academic self-efficacy, information literacy, team work, problem solving and lifelong learning skill levels than the comparison group. However, work selfefficacy, attitude towards technology, career self-efficacy skills were similar in both groups. In the group participating in Cisco certification program, it is seen that male students' lifelong learning, work self-efficacy, attitude towards technology and career self-efficacy skill levels are higher than female students. In addition, academic self-efficacy, information literacy, team work, problem solving and lifelong learning skills were similar in both groups. As of the 2011-2012 academic year, about $58 \%$ of vocational and technical high schools in Turkey are male students (MEB, 2012). In this study, the status of participation in certificate programs was more intense in men. This can be explained by the fact that the general of the students who are enrolled in vocational high schools is male.

In the literature, there are studies that support that basic technology literacy does not constitute an inequality on gender. It has been seen that women perform as well as men in terms of ICT literacy, frequency of technology use, perceived ICT skills and general attitudes towards computers (Hohlfeld, Ritzhaupt \& Barron, 2013; Sumner \& Niederman, 2004). In this study, it is concluded that female students have similar skills with male students in relation to their $21 \mathrm{st}$ century skills. However, it is clear that there is still an inequality between male and female students when informatics technologies are given as a vocational training. It is still to be studied whether this is from curricula, the way the lessons are handled or the female students' perspective on technology. 